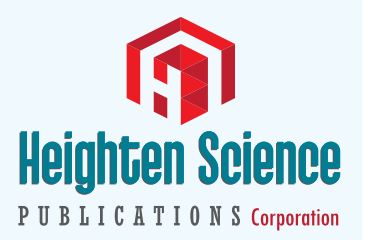

ISSN

2639-9946
*Address for Correspondence: Angelo Michele Carella, Internal Medicine Department,

T. Masselli-Mascia Hospital, San Severo (Foggia), Italy, Email: mic.carella@virgilio.it

Submitted: 19 December 2016

Approved: 06 February 2017

Published: 09 February 2017

Copyright: @ 2017 Carella AM, et al. This is an open access article distributed under the Creative Commons Attribution License, which permits unrestricted use, distribution, and reproduction in any medium, provided the original work is properly cited

Keywords: Ginseng; Hypoglycemia; Type 2 diabetes mellitus

\title{
Hypoglycemia by Ginseng in type 2 Diabetic Patient: Case Report
}

\author{
Angelo Michele Carella*, Teresa Marinelli, Armando Melfitano, \\ Michele Di Pumpo, Matteo Conte and Angelo Benvenuto \\ Internal Medicine Department, "T. Masselli-Mascia” Hospital - San Severo (Foggia), Italy
}

\section{ABSTRACT}

Ginseng extracts are often used as adaptogen to improve mental performances and well being, helping to overcome stress. Thus, in our times a lot of ginseng extracts are continuously produced and sold into commercial channels. Both Asian and Korean red ginseng (Panax ginseng) and American ginseng (Panax quinquefolius) are the most extensively used and researched. Both Panax ginseng and Panax quinquefolium contain different types of saponins, also known as ginsenosides, which are the substances that give ginseng medicinal properties. Human and animal studies showed that ginseng extracts can also have hypoglycemic effects. The mechanisms by which ginseng reduces blood glucose levels are unclear; some mechanisms have been proposed to explain its hypoglycemic effect, especially modulating effects on insulin sensitization and/or insulin secretion and regulating actions on digestion and intestinal absorption. We describe a case of hypoglycemia by ginseng in type 2 diabetic patient treated with oral hypoglycemic agents. Although, in order to provide better assessments of a sure anti-diabetic efficacy of ginseng, larger and longer randomized controlled clinical trials will be required, in our case we think that we have enough evidence to believe that the cause of hypoglycemia was ginseng. Obviously, this report should not be taken as a proof of the hypoglycemic effect of ginseng, nor it wants to be a suggestion to use ginseng in the treatment of diabetes; instead, it wants to be an alert for patients and clinicians to avoid hypoglycemia in daily clinical practice.

\section{INTRODUCTION}

Ginseng, traditionally considered a tonic herb, has been used in Chinese medicine for thousands of years and now it is often used as adaptogen to improve mental performances and well being, helping to overcome stress [1]. Thus, in our times a lot of ginseng extracts are continuously produced and sold into commercial channels [2].

Several species of ginseng have been identified, but Asian and Korean red ginseng (Panax ginseng) and American ginseng (Panax quinquefolius) are the most extensively used and researched. Both Panax ginseng and Panax quinquefolium contain in different amounts several types of saponins, also known as ginsenosides, which are the substances that give ginseng medicinal properties [1]. Human and animal studies showed that ginseng extracts can also have hypoglycemic effects [3-5].

In this report we describe a case of hypoglycemia by ginseng in type 2 diabetic patient treated with oral hypoglycemic agents.

\section{CASE REPORT}

66-year-old male with type 2 diabetes comes to our observation referring, in previous 72 hours, two episodes of postprandial symptomatic hypoglycemia, consisting of profuse sweating, tremors, pulse-pounding and transient blurred vision. In the previous hypoglycemic episode the blood glucose test measured glucose value of 47 $\mathrm{mg} / \mathrm{dL}$ and he was treated as outpatients with glucose $10 \%$ intravenous infusions. In the second episode the value of glycemia was $32 \mathrm{mg} / \mathrm{dL}$, so the patient was hospitalized. 
At admission the patient reported uncomplicated type 2 diabetes treated from some years with metformin $1000 \mathrm{mg}$ three times a day, with meals, and repaglinide 1 mg before lunch and dinner; moreover the patient reported to take a normoglycemic diet of approximately 1.700 calories per day; no alcohol consumption was reported. The patient did not take other medications to treat other conditions, since he did not report other concomitant diseases. He was a sedentary lifestyle patient, overweight (Body Mass Index $=28,3 \mathrm{~kg} / \mathrm{m}^{2}$ ), in retirement from two years, with poor compliance to glycemic self-monitoring. However, three months before the patient had done laboratory tests that revealed glycosylated hemoglobin $\left(\mathrm{Hb}_{\mathrm{A1c}}\right)$ level of $46 \mathrm{mmol} / \mathrm{mol}$ and c-peptide value of $3.7 \mathrm{ng} / \mathrm{mL}$.

During hospitalization all standard baseline investigations were normal: no abnormalities were found in basal electrocardiogram, standard thoracic radiographs, carotid and peripheral arterial echo-doppler and in ocular fund; blood pressure monitoring recorded a normotensive profile; all standard laboratory parameters were in normal range; $\mathrm{Hb}_{\mathrm{A1c}}$ level was $44 \mathrm{mmol} / \mathrm{mol}$ and c-peptide value was $3.4 \mathrm{ng} /$ $\mathrm{mL}$. Both fasting and postprandial blood glycemic values were in target range, and no hypoglycemia was registered, although we modified oral hypoglycemic agent therapy by suspending repaglinide and introducing sitagliptin $100 \mathrm{mg}$ daily. Normoglycemic diet of 1.700 calories per day was confirmed. On the sixth day the patient was discharged and the diagnosis was "iatrogenic hypoglycemia".

Approximately ten days later, the patient returned to our observation referring another hypoglycemic episode with blood glycemic value of $51 \mathrm{mg} / \mathrm{dL}$. Thus we reexamine him in details, as outpatient, and a more careful drug history revealed that the patient, as well as having regularly performed hypoglycemic therapy prescribed at discharge, had begun to take dietary supplements containing ginseng. Moreover, the patient truthfully stated that he started to take ginseng (extract G115 from roots of Panax ginseng, $200 \mathrm{mg}$ orally three times a day) about 10 days before hospitalization, because of fatigue and decreased libido that had arisen few months before. At admission the patient omitted this anamnestic detail considering it irrelevant; however, he denied having taken ginseng during hospitalization. The patient was strongly advised not to take ginseng extract later and to continue glycemic self-monitoring; oral hypoglycemic therapy was not modified. In the subsequent 6-month follow-up the patient no longer registered hypoglycemic episodes, maintaining adequate glycemic control.

\section{DISCUSSION}

In vitro and animal models indicate that ginseng might have hypoglycemic action [3-5]; similar effect has been reported in several human studies [6-9]. One of these studies showed that $200 \mathrm{mg}$ per day of orally unspecified type of ginseng, in eight weeks, led to an improvement of $\mathrm{Hb} \mathrm{A} 1 \mathrm{c}$ values in noninsulin-dependent diabetic patients [6]. Other studies have shown that American ginseng was effective in reducing postprandial glycemia in both diabetic $[7,8]$ and non-diabetic subjects $[7,9]$, although in healthy subjects this reduction was time dependent but not dose dependent; actually, in non-diabetics the hypoglycemic effect was obtained only when ginseng was given 40 minutes before oral glucose challenge test while doses of ginseng within the range of 1-3 g were equally effective [9]. In a randomized, double-blind, placebo-controlled study, the administration of Korean red ginseng $2 \mathrm{~g} / \mathrm{meal}$ ( $6 \mathrm{~g} /$ day) for 12 weeks maintained good glycemic control and improved glucose and insulin regulation in type 2 diabetic patients [10]. In another randomized, double-blind, placebo-controlled, crossover trial Panax ginseng at the dose of $2 \times 369 \mathrm{mg}$ three times daily for 4 weeks reduced insulin resistance in type 2 diabetics [11]. However, it has been shown that the anti-hyperglycemic efficacy of ginseng varies across species and is correlated to their ginsenoside composition [12]. 
Data from recent meta-analysis of randomized controlled clinical trials assert that ginseng modestly yet significantly improves fasting blood glucose in subjects with and without diabetes, although the analysis had highlighted several methodological limitations including short duration of the trials, use of unstandardized ginseng preparations with potentially varying potencies, well controlled glycemia of participants at baseline and changes in diabetic medications that could have influenced the outcomes [13]. Thus, in order to provide better assessments of a sure anti-diabetic efficacy of ginseng, larger and longer randomized controlled trials using standardized ginseng preparations are required.

In our case the patient experienced hypoglycemic episodes before hospitalization and after discharge, when he took ginseng extracts; no hypoglycemia occurred during hospitalization, when our patient has not taken ginseng. During hospitalization we have modified the hypoglycemic therapy, believing that hypoglycemia was due to repaglinide, drug known for its action stimulating release of insulin from the pancreas; nevertheless, after discharge hypoglycemia occurred while the patient was taking metformin and sitagliptin, two drugs that rarely cause hypoglycemia [14]. Thus we think there are enough evidence to believe that the cause of hypoglycemia was ginseng; moreover, after discontinuation of ginseng the patient no longer experienced hypoglycemia. A positive interaction between ginseng extracts and oral antidiabetic agents might nevertheless be a possibility.

The mechanisms by which ginseng reduces blood glucose levels are unclear; some mechanisms have been proposed to explain its hypoglycemic activity, especially modulating effects on insulin sensitization $[5,15]$ and/or insulin secretion [16] and a regulating action on digestion and intestinal absorption $[17,18]$.

Active components of ginseng which may play an important mediating role in these postulated processes include its polysaccharide (ginsenans), peptidoglycan (panaxans), and ginsenoside profiles. Most pharmacological actions of ginseng, however, are attributed to the involvement of ginsenosides, of which there are 3 classes: 20(S)protopanaxadiols, 20(S)-protopanaxatriols, and oleanic acid-ginsenoside [19].

It is known that the early phase of insulin secretion requires nitric oxide [20] and there is evidence that ginsenosides are able to modulate nitric oxide synthesis [21]. Moreover, it has been shown in animal studies that ginsenosides increases glucose uptake into sheep erythrocytes [15] and into adipocytes or skeletal muscle cells through glucose transporter-4 (GLUT4) overexpression [22,23], consequent to increased activity of peroxisome proliferator-activated receptor gamma (PPAR- $\gamma$ ) $[24,25]$.

Several studies have shown that ginsenosides can ameliorate metabolic diseases such as diabetes, obesity and nonalcoholic fatty liver disease via AMP-activated protein kinase (AMPK) signaling pathway [23,26-30]; moreover it has been also shown that ginsenoside-Rb2 intensifies the activity of glucokinase and phosphofructokinase, two rate-limiting glycolytic enzymes, while decreases the activity of glucose-6-phophatase, a rate limiting gluconeogenic enzyme [31,32]. Other studies demonstrate both American and Korean red ginseng increase insulin production and secretion through inhibition of cytokine-induced $\beta$-cell apoptosis $[33,34]$ and presumably by acting on ATP-sensitive $\mathrm{K}+$ channels [35].

Finally, in other studies, ginseng has been able to inhibit gastric secretion in rats [18] and to reduce sugar absorption in isolated rat and human duodenal samples [36]; these observations may suggest a delaying or inhibiting effect on the intestinal absorption of carbohydrates. On the other hand, in some clinical trials $[37,38]$ ginseng was found to have no effect on any glucoregulatory parameter investigated, including insulin sensitivity, suggesting that the use of ginseng has no effect on glucose regulation. 
Obviously our report should not be taken as a proof of the hypoglycemic effect of ginseng, nor wants to be a suggestion to use ginseng in the treatment of diabetes; instead, it wants to be an alert for patients and clinicians to avoid hypoglycemia, particularly in diabetic patients with optimal glycemic control and treated with antidiabetic drugs stimulating insulin secretion.

\section{CONCLUSION}

Although data from animal and in vitro studies have shown that ginseng extract and its active components can have hypoglycemic activity and beneficial effects on glucose and lipid metabolism, the results from clinical studies are unclear because of confounding factors which could have influenced the outcomes. Therefore, in order to provide better assessments of a sure anti-diabetic efficacy of ginseng larger and longer randomized controlled clinical trials will be required. However, we think the potential hypoglycemic effect of ginseng should be taken into account in daily clinical practice to avoid hypoglycemia, particularly in diabetic patients with optimal glycemic control and in those treated with antidiabetic drugs stimulating insulin secretion.

\section{REFERENCES}

1. Christensen LP. Ginsenosides chemistry, biosynthesis, analysis, and potential health effects. Adv Food Nutr Res. 2009; 55: 1-99. Ref.: https://goo.gl/rnMBwu

2. Baeg IH, So SH. The world ginseng market and the ginseng (Korea). J Ginseng Res. 2013; 37: 1-7. Ref.: https://goo.gl/Y3hfc3

3. Oshima $\mathrm{Y}$, Sato $\mathrm{K}$, Hikino $\mathrm{H}$. Isolation and hypoglycemic activity of quinquefolans $\mathrm{A}, \mathrm{B}$, and $\mathrm{C}$, glycans of Panax quinquefolium roots. J Nat Prod. 1987; 50: 188-90. Ref.: https://goo.gl/J0u0MP

4. Martinez B, Staba EJ. The physiological effects of Aralia, Panax and Eleutherococcus on exercised rats. Jpn J Pharmacol. 1984; 35: 79-85. Ref.: https://goo.gl/10yCDs

5. Ohnishi $Y$, Takagi S, Miura $T$, Usami $M$, Kako $M$, et al. Effect of ginseng radix on GLUT2 protein content in mouse liver in normal and epinephrineinduced hyperglycemic mice. Biol Pharm Bull. 1996; 19: 1238-1240. Ref.: https://goo.gl/7I2DWv

6. Sotaniemi EA, Haapakoski E, Rautio A. Ginseng therapy in noninsulin-dependent diabetic patients. Diabetes Care. 1995; 18: 1373-1375. Ref.: https://goo.gl/ICOgPu

7. Vuksan V, Sieveniper JL, Koo VYY, Thomas Francis, Uljana Beljan-Zdravkovic, et al. American ginseng reduces postprandial glycemia in nondiabetic and diabetic individuals. Arch Intern Med. 2000; 160: 1009-1013. Ref.: https://goo.gl/kJwYrb

8. Vuksan V, Stavro MP, Sievenpiper JL, Beljan-Zdravkovic U, Leiter LA, et al. Similar postprandia glycemic reductions with escalation of dose and administration time of American ginseng in type 2 diabetes. Diabetes Care. 2000; 23: 1221-1226. Ref.: https://goo.gl/WZefoA

9. Vuksan V, Sievenpiper JL, Wong J, Zheng Xu, Uljana Beljan-Zdravkovic, et al. American ginseng (Panax quinquefolius L.) attenuates postprandial glycemia in a time-dependent but not dose-dependent manner in healthy individuals. Am J Clin Nutr. 2001; 73: 753-758. Ref.: https://goo.gl/2Jaayp

10. Vuksan V, Sung MK, Sievenpiper JL, Stavro PM, Alexandra LJ, et al. Korean red ginseng (Panax ginseng) improves glucose and insulin regulation in well-controlled, type 2 diabetes: results of a randomized, double-blind, placebo-controlled study of efficacy and safety. Nutr Metab Cardiovasc Dis. 2008; 18: 46-56. Ref.: https://goo.gl/JAJF3B

11. Ma SW, Benzie IF, Chu TT, Fok BSP, Tomlinson B, et al. Effect of Panax ginseng supplementation on biomarkers of glucose tolerance, antioxidant status and oxidative stress in type 2 diabetic subjects: results of a placebo-controlled human intervention trial. Diabetes Obes Metab. 2008; 10 : 1125-1127. Ref.: https://goo.gl/SkMNQB

12. Sievenpiper JL, Arnason JT, Vidgen E, Lawrence LA, Vladimir V. A systematic quantitative analysis of the literature of the high variability in ginseng (Panax spp.): should ginseng be trusted in diabetes? Diabetes Care. 2004; 27: 839-840. Ref.: https://goo.gl/sxrgqn

13. Shishtar E, Sievenpiper JL, Djedovic V, Adrian IC, Vanessa Ha, et al. The effect of ginseng (the genus panax) on glycemic control: a systematic review and meta-analysis of randomized controlled clinical trials. PLoSOne. 2014; 9: e107391. Ref.: https://goo.gl/7C08W5

14. Zonszein J, Groop PH. Strategies for Diabetes Management: Using Newer Oral Combination Therapies Early in the Disease. Diabetes Ther. 2016; 7: 621-639. Ref.: https://goo.gl/9RRI9M 
15. Hasegawa H, Matsumiya S, Murakami C, Tomonori K, Ryoji K, et al. Interactions of ginseng extract, ginseng separated fractions, and some triterpenoid saponins with glucose transporters in sheep erythrocytes. Planta Med. 1994; 60: 153-157. Ref.: https://goo.gl/RHV1vb

16. Kimura M, Waki I, Chujo T, Takeo K, Chizuko H, et al. Effects of hypoglycemic components in ginseng radix on blood insulin level in alloxan diabetic mice and on insulin release from perfused rat pancreas. J Pharmacobiodyn. 1981; 4: 410-417. Ref.: https://goo.gl/NE4RvE

17. Yuan CS, Wu JA, Lowell T, Maojian G. Gut and brain effects of American ginseng root on brainstem neuronal activities in rats. Am J Chin Med. 1998; 26: 47-55. Ref.: https://goo.gl/AYKG8x

18. Suzuki $Y$, Ito $Y$, Konno $C$, Furuya $T$. Effects of tissue cultured ginseng on gastric secretion and pepsin activity. Yakugaku Zasshi. 1991; 111: 770-774. Ref.: https://goo.gl/SNJGsY

19. Attele AS, Wu JA, Yuan CS. Ginseng pharmacology: multiple constituents and multiple actions. Biochem Pharmacol. 1999; 58: 1685-1693. Ref.: https://goo.gl/P4SNWq

20. Spinas GA, Laffranchi R, Francoys I, David I, Richter C, et al. The early phase of glucose-stimulated insulin secretion requires nitric oxide. Diabetologia. 1998; 41: 292-299. Ref.: https://goo.gl/KRI5SX

21. Gillis CN. Panax ginseng pharmacology: a nitric oxide link? Biochem Pharmacol. 1997; 54: 1-8. Ref.: https://goo.gl//movHd

22. Kim JJ, Xiao H, Tan Y, Zhong ZW, Seale JP, et al. The effects and mechanism of saponins of Panax notoginseng on glucose metabolism in 3T3-L1 cells. Am J Chin Med. 2009; 37: 1179-1189. Ref.: https://goo.gl/U4K5Fk

23. Kim DY, Yuan HD, Huang B, Hai YQ, Sung HC. Ginsenoside 20(R)-Rg3 stimulates glucose uptake in C2C12 myotubes via CaMKK-AMPK pathways. Food Sci Biotechnol. 2010; 19: 1277-1282. Ref.: https://goo.gl/rGja1K

24. Han KL, Jung MH, Sohn JH, Hwang JK. Ginsenoside 20S-protopanaxatriol (PPT) activates peroxisome proliferator- activated receptor gamma (PPARgamma) in 3T3-L1 adipocytes. Biol Pharm Bull. 2006; 29: 110-113. Ref.: https://goo.gl/COA3pR

25. Lee HJ, Lee YH, Park SK, Kang ES, Jeong HK, et al. Korean red ginseng (Panax ginseng) improves insulin sensitivity and attenuates the development of diabetes in Otsuka Long-Evans Tokushima fatty rats. Metabolism. 2009; 58: 1170-1177. Ref.: https://goo.gl/17RQGj

26. Quan HY, Yuan HD, Jung MS, Ko SK, Park YG, et al. Ginsenoside Re lowers blood glucose and lipid levels via activation of AMP-activated protein kinase in HepG2 cells and high-fat diet fed mice. Int J Mol Med. 2012; 29: 73-80. Ref.: https://goo.gl/TA9CBo

27. Kim SJ, Yuan HD, Chung SH. Ginsenoside Rg1 suppresses hepatic glucose production via AMP-activated protein kinase in HepG2 cells. Biol Pharm Bull. 2010; 33: 325-328. Ref.: https://goo.gl/PFYfj1

28. Han GC, Ko SK, Sung JH, Chung SH. Compound K enhances insulin secretion with benef cial metabolic effects in db/db mice. J Agric Food Chem. 2007; 55: 10641-10648. Ref.: https://goo.gl/4qeDbr

29. Yuan HD, Kim SJ, Chung SH. Benefi cial effects of IH- 901 on glucose and lipid metabolisms via activating adenosine monophosphate-activated protein kinase and phosphatidylinositol-3 kinase pathways. Metabolism. 2011; 60: 43-51. Ref.: https://goo.gl/OGWTZI

30. Yuan HD, Kim DY, Quan HY, Kim SJ, Jung MS, et al, Chung SH. Ginsenoside Rg2 induces orphan nuclear receptor SHP gene expression and inactivates GSK3 $\beta$ via AMPactivated protein kinase to inhibit hepatic glucose production in HepG2 cells. Chem Biol Interact. 2012; 195: 35-42. Ref.: https://goo.gl/975l83

31. Yokozawa $T$, Kobayashi $T$, Oura $H$, Kawashima $Y$. Stimulation of lipid and sugar metabolism in ginsenoside-Rb2 treated rats. Chem Pharm Bull. 1984; 32: 2766-2772. Ref.: https://goo.gl/EO6g9R

32. Yokozawa $\mathrm{T}$, Kobayashi $\mathrm{T}$, Oura $\mathrm{H}$, Kawashima $\mathrm{Y}$. Studies on the mechanism of the hypoglycemic activity of ginsenoside-Rb2 in streptozotocin-diabetic rats. Chem Pharm Bull. 1985; 33: 869-872. Ref.: https://goo.gl/OAOoqd

33. Luo JZ, Luo L. American ginseng stimulates insulin production and prevents apoptosis through regulation of uncoupling protein-2 in cultured beta cells. Evid Based Complement Alternat Med. 2006; 3: 365-372. Ref.: https://goo.gl/FiOstu

34. Kim HY, Kim K. Protective effect of ginseng on cytokineinduced apoptosis in pancreatic beta-cells. J Agric Food Chem. 2007; 55: 2816-2823. Ref.: https://goo.gl/OFSoOr

35. Choi YS, Han GC, Han EJ, Park KJ, Park JS, et al. Antidiabetic activity of $\mathrm{IH}-901 \mathrm{in} \mathrm{db} / \mathrm{db}$ mice. Yakhak Hoeji. 2006; 50: 345-350. Ref.: https://goo.gl/70N70w

36. Onomura M, Tsukada H, Fukuda K, Masaya $H$, Hiroshi $N$, et al. Effects of ginseng radix on sugar absorption in the small intestine. Am J Chin Med. 1999; 27: 347-354. Ref.: https://goo.gl/ac5YP5 
37. Reay JL, Scholey AB, Milne A, Fenwick J, David OK. Panax ginseng has no effect on indices of glucose regulation following acute or chronic ingestion in healthy volunteers. $\mathrm{Br} \mathrm{J}$ Nutr. 2009; 101: 1673-1678. Ref.: https://goo.gl/keqZot

38. Reeds DN, Patterson BW, Okunade A, John OH, Kenneth SP, et al. Ginseng and ginsenoside Re do not improve $\beta$-cell function or insulin sensitivity in overweight and obese subjects with impaired glucose tolerance or diabetes. Diabetes Care. 2011; 34: 1071-1076. Ref.: https://goo.gl/4FqdXR 